\title{
CTAG2 wt Allele
}

National Cancer Institute

\section{Source}

National Cancer Institute. CTAG2 wt Allele. NCI Thesaurus. Code C104047.

Human CTAG2 wild-type allele is located in the vicinity of Xq28 and is approximately $2 \mathrm{~kb}$ in length. This allele, which encodes cancer/testis antigen 2 protein, may be involved in tumorigenesis of melanomas, sarcomas, and other tumor types. 